\title{
Shprintzen-Goldberg syndrome with plagiocephaly: A case report
}

\section{Zespół Shprintzena-Goldberga ze skośnogłowiem - opis przypadku}

\author{
Chaitali Hambire $^{A-F}$ \\ Department of Pediatric Dentistry, Government Dental College and Hospital, Aurangabad, India \\ A - research concept and design; $\mathrm{B}$ - collection and/or assembly of data; $\mathrm{C}$ - data analysis and interpretation; \\ $D$ - writing the article; $E$ - critical revision of the article; $F$ - final approval of the article
}

\section{Address for correspondence \\ Chaitali Hambire}

E-mail: chaitalikmirajkar@gmail.com

\section{Funding sources}

None declared

Conflict of interest

None declared

Received on March 25, 2019

Reviewed on April 14, 2019

Accepted on April 30, 2019

Published online on September 30, 2019

Cite as

Hambire C. Shprintzen-Goldberg syndrome with

plagiocephaly: A case report. Dent Med Probl.

2019;56(3):307-310. doi:10.17219/dmp/109111

DOI

$10.17219 / \mathrm{dmp} / 109111$

Copyright

(C) 2019 by Wroclaw Medical University

This is an article distributed under the terms of the

Creative Commons Attribution 3.0 Unported License (CC BY 3.0)

(https://creativecommons.org/licenses/by/3.0/)

\begin{abstract}
The Shprintzen-Goldberg syndrome (SGS) is an autosomal dominant disorder with multiple congenital abnormalities. It is the result of de novo gene mutations. Recently, mutations in the SKI gene are considered to be related to this syndrome. This gene is responsible for the manufacturing of protein which regulates the transforming growth factor beta (TGF- $\beta$ ) signaling pathway. There are characteristic craniofacial, skeletal, neurological, and connective tissue abnormalities associated with SGS.

This is a case report of a 6-year-old male child who reported to the Department of Pediatric Dentistry at the Government Dental College and Hospital, Aurangabad, India, with decayed teeth. He had craniofacial, skeletal, cardiovascular, and other abnormalities suggestive of SGS. The patient had a tall forehead with plagiocephaly and a high-arched palate with hypoplastic teeth. His ears were apparently low-set with posterior rotation. The child had eyes with proptosis, myopia, hypertelorism, and down-slanting palpebral fissures. The child had moderate mental retardation with craniofacial features typical of this syndrome. The Shprintzen-Goldberg syndrome has many similarities with the Marfan syndrome (MFS) or the Loeys-Dietz syndrome (LDS) due to considerable phenotypic overlapping.
\end{abstract}

Key words: strabismus, Shprintzen-Goldberg syndrome, high-arched palate, plagiocephaly

Słowa kluczowe: zez, syndrom Shprintzena-Goldberga, podniebienie gotyckie, skośnogłowie 


\section{Introduction}

The Shprintzen-Goldberg syndrome (SGS) is a very rare congenital disorder affecting craniofacial, skeletal, neurological, and connective tissues. Craniosynostosis with marfanoid habitus and characteristic facial dysmorphism are the key features of this syndrome. ${ }^{1-3}$ Dolichocephaly, low-set ears, a high prominent forehead, proptosis, hypertelorism, divergent strabismus, down-slanting eyes, a higharched narrow palate, and maxillary hypoplasia are the most frequent craniofacial abnormalities in SGS. ${ }^{1,2}$ Arachnodactyly, flat feet, pectus deformity, scoliosis, and hypermobile joints are the skeletal abnormalities. ${ }^{1}$ Myopia and telecanthus are some other important ophthalmic features characteristic of SGS. ${ }^{2}$ Affected individuals also suffer from hypotonia, cardiac defects and umbilical hernia. ${ }^{3-5}$

The Shprintzen-Goldberg syndrome has many similarities with the Marfan syndrome (MFS) or the Loeys -Dietz syndrome (LDS) due to considerable phenotypic overlapping. ${ }^{3-5}$ Differential diagnosis includes MFS, LDS, the Idaho syndrome-II, the Antley-Bixler syndrome (ABS), congenital contractural arachnodactyly (CCA), and several other craniosynostotic syndromes. ${ }^{4,5}$ There is no male or female predilection. The development of the affected individual is delayed, with mild to moderate intellectual disability.

This is a case report of a 6-year-old male child who reported to the Department of Pediatric Dentistry at the Government Dental College and Hospital, Aurangabad, India, with decayed teeth. He had craniofacial, skeletal, cardiovascular, and other abnormalities suggestive of SGS.

\section{Case report}

A six-year-old male patient was brought to our department by his parents with a chief complaint of decayed teeth. The child was carried by his father, as he was unable to walk without support. The parents were healthy, in a non-consanguineous marriage. They had a poor socioeconomic background. The boy was their first-born child. He was born without any history of complications during pregnancy. There was no history of known exposure to teratogens during the perinatal period. His parents reported delayed developmental milestones. The child had defective hearing and speech. He was not able to express his problems. The parents reported that the child did not attend any school. The boy was suffering from moderate mental retardation. He presented with facial dysmorphism and musculoskeletal abnormalities.

Our physical examination revealed that the boy's limbs were weak and he had difficulty with walking. He had a tall forehead with plagiocephaly. His ears were apparently low-set with posterior rotation. The child had eyes with proptosis, myopia, hypertelorism, and down-slanting palpebral fissures. He was suffering from strabismus. His nasal bridge was flattened. The face profile was convex with marked facial asymmetry. His lips were potentially competent. The skeletal findings included pectus carinatum and flat feet. Umbilical hernia was also present (Fig. 1-3). The intraoral examination revealed that the child had deciduous dentition with multiple carious teeth (Fig. 4). His maxillary arch

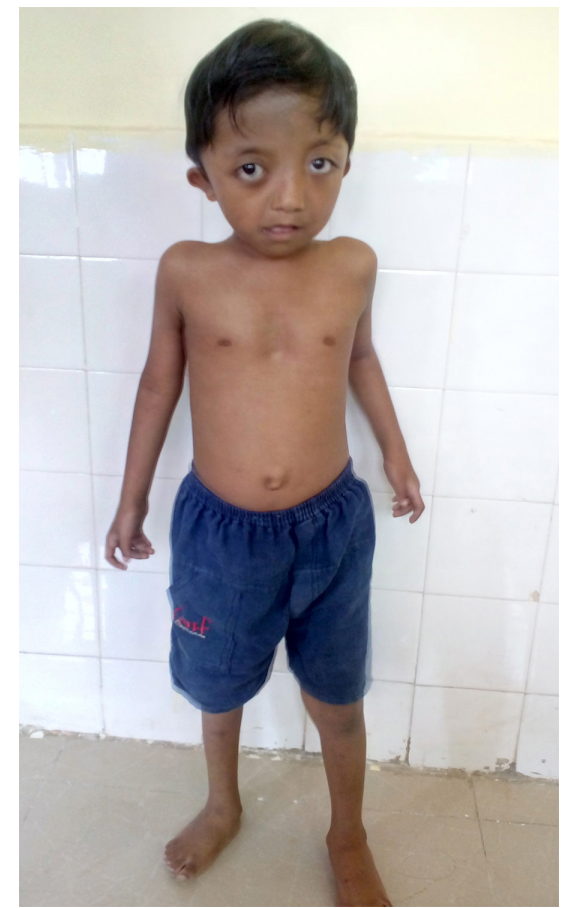

Fig. 1. Frontal view of the patient

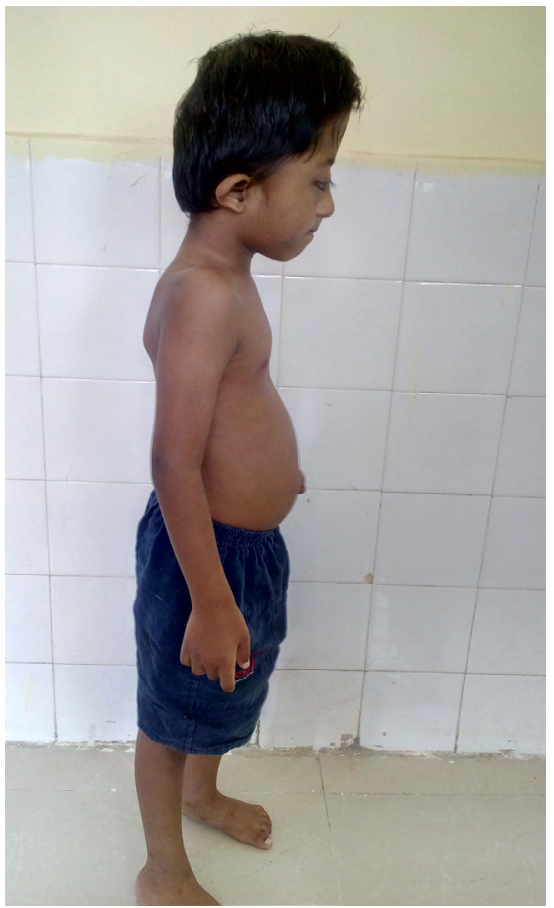

Fig. 2. Lateral view of the patient

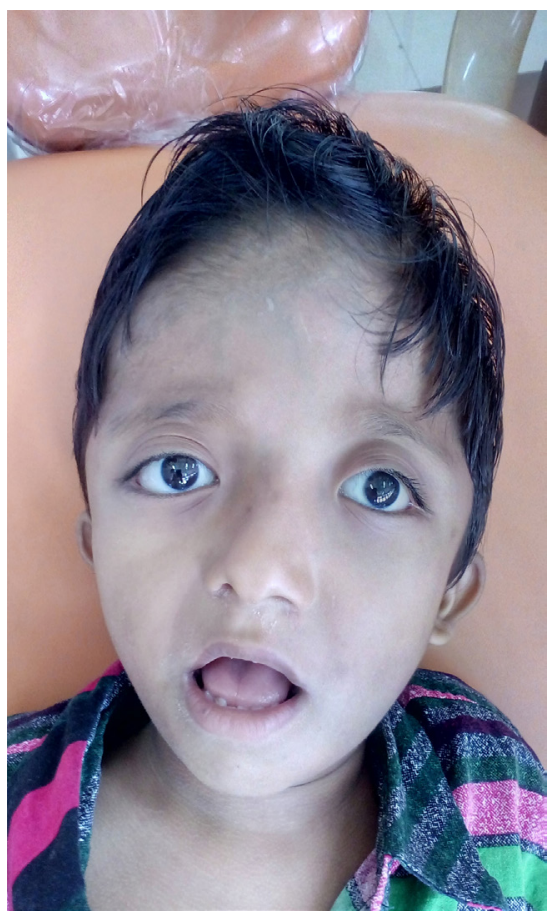

Fig. 3. Craniofacial features 


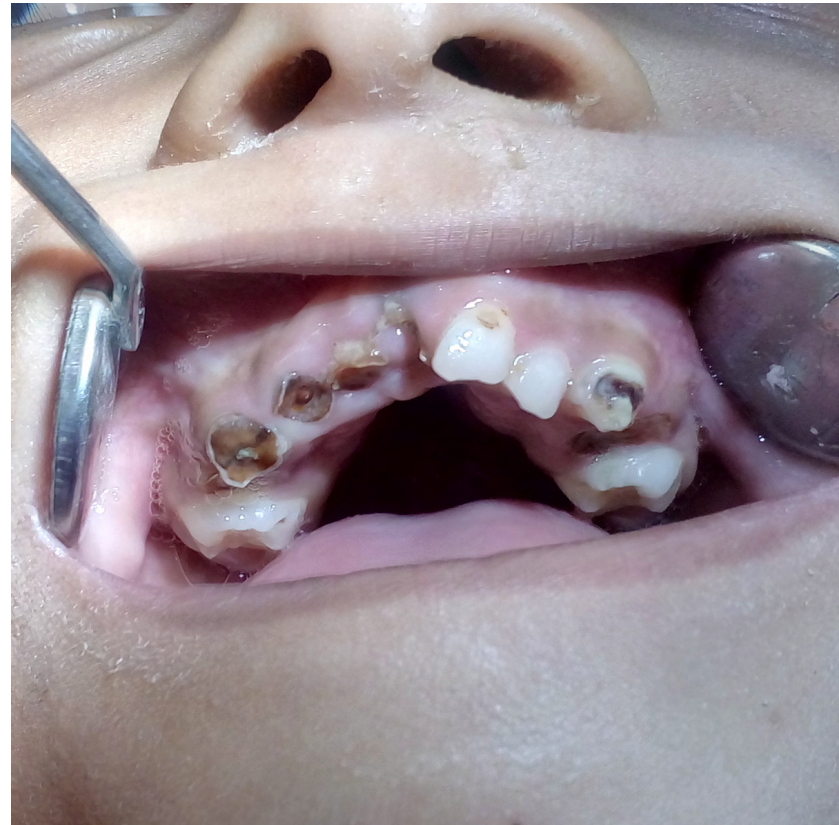

Fig. 4. Decayed and malaligned teeth

was high with a narrow and deep palate. He had a negative history of thumb sucking. Crowding was present in the mandibular teeth. The maxilla was hypoplastic. Besides, the child had congenital heart disease with aortic regurgitation.

In 1998, Greally et al. described the clinical features typical of SGS. ${ }^{1}$ Based on the unusual and atypical clinical findings, the patient was subsequently diagnosed to be a possible case of SGS.

\section{Discussion}

The Shprintzen-Goldberg syndrome is sometimes called the marfanoid-craniosynostosis syndrome, the Shprintzen-Goldberg craniosynostosis syndrome, craniosynostosis with arachnodactyly and abdominal herniae, marfanoid disorder with craniosynostosis, or type I marfanoid-craniosynostosis syndrome. Shprintzen and Goldberg described this syndrome in 1982. Sugarman and Vogel were the first to report this condition in 1981, in a 17-year-old male with plagiocephaly, multiple craniofacial, vertebral and skeletal anomalies, umbilical and inguinal herniae, hypotonia, and mental retardation. ${ }^{6}$ This syndrome has a variable phenotypic expression, as it involves the abnormalities of skeletal, connective, craniofacial, cardiovascular, and neurological tissues. Greally et al. gave a thorough review of the clinical features of SGS (Table 1). ${ }^{1}$

Mutations in the SKI gene are considered to be the most common etiology. This gene is responsible for the manufacturing of protein which regulates the transforming growth factor beta (TGF- $\beta$ ) signaling pathway. The TGF- $\beta$ signaling pathway is responsible for the regulation of cellular proliferation, differentiation, apoptosis, and motility. The SKI protein plays a crucial role in the development of the tissues of the skull, bones, skin, and brain. In this syndrome, a mutation in the SKI gene alters the SKI protein. This altered protein is not able to attach to proteins in the TGF- $\beta$ pathway and to block signaling. This results in an abnormally active TGF- $\beta$ pathway. Excess signaling of TGF- $\beta$ affects the gene activity.

Table 1. Characteristic features of the Shprintzen-Goldberg syndrome (SGS) as described by Greally et al. ${ }^{1}$

\begin{tabular}{|c|c|c|}
\hline \multicolumn{2}{|c|}{ Features } & Description \\
\hline \multicolumn{2}{|c|}{ Craniosynostosis } & premature fusion of certain skull bones, involving the coronal, sagittal or lambdoid sutures \\
\hline \multirow{4}{*}{$\begin{array}{l}\text { Craniofacial } \\
\text { features }\end{array}$} & head & dolichocephaly, scaphocephaly, plagiocephaly, prominent forehead \\
\hline & $\begin{array}{l}\text { palate } \\
\text { and jaws }\end{array}$ & $\begin{array}{l}\text { flattening/hypoplasia of the malar bone, high and narrow palate with prominent palatine ridges, } \\
\text { micrognathia and/or retrognathia }\end{array}$ \\
\hline & ears & apparently low-set with posterior rotation \\
\hline & eyes & myopia, proptosis, strabismus, hypertelorism, telecanthus, down-slanting palpebral fissures \\
\hline \multicolumn{2}{|c|}{ Neurological abnormalities } & mild to moderate intellectual disability, delayed motor and cognitive milestones \\
\hline \multicolumn{2}{|c|}{ Brain abnormalities } & hydrocephalus, dilatation of the lateral ventricles, Chiari malformation type I \\
\hline \multicolumn{2}{|c|}{ Cardiovascular abnormalities } & prolapsed mitral valve, dilatation of the aortic root, mitral regurgitation/incompetence, aortic regurgitation \\
\hline \multirow{5}{*}{$\begin{array}{l}\text { Skeletal } \\
\text { anomalies }\end{array}$} & joints & hypermobility of joints, osteopenia \\
\hline & skull & craniosynostosis, wide anterior fontanel \\
\hline & $\begin{array}{l}\text { spine } \\
\text { and vertebrae }\end{array}$ & $\begin{array}{c}\text { C1-C2 vertebral abnormality (fusion or subluxation), scoliosis (abnormal side-to-side curvature of the spine), } \\
\text { square-shaped vertebral bodies }\end{array}$ \\
\hline & extremities & $\begin{array}{l}\text { dolichostenomelia, arachnodactyly (long, slender fingers), camptodactyly (1 or more fingers permanently bent), } \\
\text { metatarsus adductus, talipes equinovarus, flat feet }\end{array}$ \\
\hline & chest & pectus excavatum (sunken chest) or pectus carinatum (protruding chest), thin ribs, 13 pairs of ribs \\
\hline \multicolumn{2}{|c|}{ Genitourinary abnormalities } & inguinal hernia, cryptorchidism in males \\
\hline \multicolumn{2}{|c|}{ Other findings } & $\begin{array}{c}\text { herniae and abdominal wall defects, loss of subcutaneous fat, arterial tortuosity and aneurysms, broad/bifid uvula, } \\
\text { cleft palate, dural ectasia }\end{array}$ \\
\hline
\end{tabular}


Consequently, the development of many body systems, including the bones and brain, is disturbed, producing a wide range of signs and symptoms of SGS.,7 In a case report describing a Japanese boy with clinical findings consistent with SGS, Kosaki et al. identified a 3662E-A transition (134797.0045) resulting in the cys 1221-to-tyr (C $1221 \mathrm{Y}$ ) substitution in the FBN 1 gene. ${ }^{8}$ A defect in the gene present on chromosome 15 is also considered to be responsible for this syndrome. ${ }^{9}$ Germline mosaicism with mutations in 3 genomic loci have been linked to SGS, thereby making it a molecularly heterogeneous disorder. ${ }^{10}$ The $4^{\text {th }}$ region (15q25-qter) is also considered to be the cause of this syndrome. ${ }^{11}$ Most investigators believe that multiple genes are responsible for a single phenotype. Thus, mutations in other genes may also be related to SGS.

The differential diagnosis of SGS should embrace LDS, MFS, CCA, frontometaphyseal dysplasia, the Melnick -Needles syndrome (MNS), the Idaho syndrome-II, and ABS. ${ }^{12-23}$

The occurrence of SGS is very rare. As of 2016, approx. 60 cases of SGS have been described in the medical literature since the first case was reported in the original publication by Sugarman and Vogel in 1981.6,24

In our case, the 6-year-old male child had the majority of the characteristic features of SGS as described by Greally et al. ${ }^{1}$ The child had moderate mental retardation and craniofacial features typical of this syndrome. His skeletal, cardiovascular and neurological features could also be associated with SGS.

There was no positive family history in our case. The parents and siblings of the patient were without any abnormalities. The Shprintzen-Goldberg syndrome is mostly the result of de novo gene mutations. In very rare cases, this syndrome is inherited from normal parents with defective or altered genes.

\section{Conclusions}

Patients with SGS can have variable phenotypes and abnormalities. A thorough and meticulous clinical examination along with a detailed history are required to diagnose this syndrome. This condition is not life-threatening, but the patient can suffer from the complications arising from cardiac, respiratory or skeletal abnormalities. A team of a pediatrician, cardiologist, ophthalmologist, radiologist, speech pathologist, physical therapist, and surgeon is needed to treat and manage such patients. Standard therapies are limited to symptom management, such as the repair of aneurysms and heart valves as well as spinal and chest malformations, and the operation of craniosynostosis, which has to be done in the $1^{\text {st }}$ year of life.

\section{ORCID iDs}

Chaitali Hambire (i) https://orcid.org/0000-0001-7672-0184

\section{References}

1. Greally MT, Carey JC, Milewicz DM, et al. Shprintzen-Goldberg syndrome: A clinical analysis. Am J Med Genet.1998;76(3):202-212.

2. Topouzelis N, Markovitsi E, Antoniades K. Shprintzen-Goldberg syndrome: Case report. Cleft Palate Craniofac J. 2003;40(4):433-436.

3. Shprintzen RJ, Goldberg RB. A recurrent pattern syndrome of craniosynostosis associated with arachnodactyly and abdominal hernias. J Craniofac Genet Dev Biol. 1982;2(1):65-74.

4. Doyle AJ, Doyle JJ, Bessling SL, et al. Mutations in the TGF- $\beta$ repressor SKI cause Shprintzen-Goldberg syndrome with aortic aneurysm. Nat Genet. 2012;44(11):1249-1254.

5. Robinson PN, Neumann LM, Demuth S, et al. Shprintzen-Goldberg syndrome: Fourteen new patients and a clinical analysis. Am J Med Genet. 2005;135(3):251-262.

6. Sugarman G, Vogel MW. Craniofacial and musculoskeletal abnormalities. A questionable connective tissue disease. Synd Iden. 1981;7:16-17.

7. Carmignac V, Thevenon J, Ades L, et al. In-frame mutations in exon 1 of SKI cause dominant Shprintzen-Goldberg syndrome. Am J Hum Genet. 2012;91(5):950-957.

8. Kosaki K, Takahashi D, Udaka T, et al. Molecular pathology of Shprintzen-Goldberg syndrome. Am J Med Genet. 2006;140(1):104-108.

9. Sood S, Eldadah ZA, Krause WL, McIntosh I, Dietz HC. Mutation in fibrillin-1 and the Marfanoid-craniosynostosis (Shprintzen-Goldberg) syndrome. Nat Genet. 1996;12(2):209-211.

10. Pauliks LB, Chan KC, Lorts A, Elias ER, Cayre RO, Valdes-Cruz LM. Shprintzen-Goldberg syndrome with tetralogy of Fallot and subvalvar aortic stenosis. J Ultrasound Med. 2005;24(5):703-706.

11. Shanske AL, Goodrich JT, Ala-Kokko L, Baker S, Frederick B, Levy B. Germline mosaicism in Shprintzen-Goldberg syndrome. Am J Med Genet. 2012;158A(7):1574-1578.

12. Loeys BL, Chen J, Neptune ER, et al. A syndrome of altered cardiovascular, craniofacial, neurocognitive and skeletal development caused by mutations in TGFBR1 or TGFBR2. Nat Genet. 2005;37(3):275-281.

13. Loeys BL, Schwarze U, Holm T, et al. Aneurysm syndromes caused by mutations in the TGF-beta receptor. NEngl JMed. 2006;355(8):788-798.

14. Dietz HC. Marfan syndrome. In: Adam MP, Ardinger $\mathrm{HH}$, Pagon RA, et al., eds. GeneReviews ${ }^{\circledR}$ [Internet]. Seattle, WA: University of Washington, Seattle; 1993-2014; 2001 [updated 2017]. http://www. ncbi.nlm.nih.gov/books/NBK1335. Accessed January 17, 2019.

15. Godfrey M. Congenital contractural arachnodactyly. In: Adam MP, Ardinger HH, Pagon RA, et al., eds. GeneReviews ${ }^{\circledR}$ [Internet]. Seattle, WA: University of Washington, Seattle; 1993-2014; 2001 [updated 2012]. http://www.ncbi.nlm.nih.gov/books/NBK1386. Accessed January 18, 2019.

16. Godfrey M. Fibrillin-2 mutations in congenital contractural arachnodactyly. In: Robinson PN, Godfrey M, eds. Marfan Syndrome: A Primer for Clinicians and Scientists. New York, NY: Plenum; 2004:123-129.

17. Gorlin RJ, Cohen MM Jr. Frontometaphyseal dysplasia. A new syndrome. Am J Dis Child. 1969;118(3):487-494.

18. Danks DM, Mayne V. Frontometaphyseal dysplasia: A progressive disease of bone and connective tissue. Birth Defects Orig Artic Ser. 1974;10(12):57-60.

19. Holt JF, Thompson GR, Arenberg IK. Frontometaphyseal dysplasia. Radiol Clin North Am. 1972;10(2):225-243.

20. Melnick JC, Needles CF. An undiagnosed bone dysplasia. A 2-family study of 4 generations and 3 generations. Am J Roentgenol Radium Ther Nucl Med. 1966;97(1):39-48.

21. LaMontagne AE. Urological manifestations of the Melnick-Needles syndrome: A case report and review of the literature. J Urol. 1991;145(5):1020-1021.

22. Stoll C. Shprintzen-Goldberg marfanoid syndrome: A case followed up for 24 years. Clin Dysmorphol. 2002;11(1):1-7.

23. Antley R, Bixler D. Trapezoidocephaly, midfacial hypoplasia and cartilage abnormalities with multiple synostoses and skeletal fractures. Birth Defects Orig Artic Ser. 1975;11(2):397-401.

24. Greally MT. Shprintzen-Goldberg syndrome. In: Adam MP, Ardinger $\mathrm{HH}$, Pagon RA, et al., eds. GeneReviews ${ }^{\circledR}$ [Internet]. Seattle, WA: University of Washington, Seattle; 1993-2014; 2006 [updated 2013]. http://www.ncbi.nlm.nih.gov/books/NBK1277. Accessed January 21, 2019. 